\title{
Single-port laparoscopic surgery in gynecology-current status
}

\author{
William Kondo • Reitan Ribeiro • \\ Monica Tessmann Zomer
}

Received: 25 February 2012 / Accepted: 1 April 2012 / Published online: 25 April 2012

(C) Springer-Verlag 2012

\begin{abstract}
The objective of this study is to report the current status on single-port laparoscopic surgery in gynecology. A systematic MEDLINE review of the English language literature from 2007 to 2011 was performed using the search term "single-port surgery," which contained information on single-port laparoscopic surgery in gynecology. Overall, 1,152 patients (26 studies) were included in the analysis. The operative time varied according to the type of procedure. The conversion rate to conventional laparoscopy was $1.99 \%$, and the conversion rate to laparotomy was $0.35 \%$. Postoperative complications were encountered in $1.48 \%$ of cases. Different gynecologic procedures have been effectively performed by means of single-port laparoscopic surgery. The procedure seems to be feasible, reproducible, and safe. Reduced pain and improved cosmesis are supposed to be the potential advantages of these procedures, but it was not completely confirmed yet! Further studies are still necessary to establish the real benefits of this new surgical approach over the traditional multi-port laparoscopy.
\end{abstract}

W. Kondo $\cdot$ M. T. Zomer

Sugisawa Medical Center,

Curitiba, Paraná, Brazil

W. Kondo $\cdot$ R. Ribeiro $\cdot$ M. T. Zomer

Red Cross Hospital,

Curitiba, Paraná, Brazil

W. Kondo $\cdot$ R. Ribeiro $\cdot$ M. T. Zomer

Vita Batel Hospital,

Curitiba, Paraná, Brazil

W. Kondo $(\bowtie)$

Av. Getulio Vargas, 3163 ap 21, 80240-041 Curitiba, Paraná, Brazil e-mail: williamkondo@yahoo.com URL: drwilliamkondo.site.med.br
Keywords Single-port surgery · Laparoscopic surgery · Gynecology $\cdot$ Minimally invasive surgery

\section{Background}

Laparoscopic surgery has increasingly assumed a central role in the management of benign and malignant conditions in gynecology [1]. In the last years, various efforts have been made to further minimize the invasiveness of traditional laparoscopy reducing the port size and/or the port number [2-6]. As a result of these efforts, single-port transumbilical laparoscopic surgery has been introduced as a further development of conventional laparoscopy. In this technique, the procedure requires only one incision at the umbilicus, reducing the morbidity of additional incisions (epigastric vessels injury, operative wound infection, visceral organ damage) and improving the final cosmetic outcome [2, 7].

Several terms have been used to describe this surgical procedure [8]: single-port surgery, single-incision laparoscopic surgery (SILS), single-port access surgery, transumbilical endoscopic surgery, laparoendoscopic single-site (LESS) surgery, and embryonic natural orifice transumbilical endoscopic surgery. No matter what term is used, the single-incision approach to gynecological diseases is not a new idea. It has been used in gynecology as early as 1969, when a laparoscopic tubal ligation was described by Wheeless [9]. In 1973, Wheeless and Thompson [10] reported on 2,600 cases of one-incision laparoscopic tubal ligation. The first hysterectomy with bilateral salpingo-oophorectomy performed by means of laparoscopic single-incision access was described by Pelosi and Pelosi [11], in 1991.

Despite the technical challenges associated with complex intracorporeal maneuvers, lack of instrument triangulation, limited traction of tissue, and external crowding and clashing $[3,12]$, single-port laparoscopic surgery has been successfully 
Table 1 Twenty-six studies including 1,152 women undergoing single-port laparoscopic surgery for gynecological pathologies

\begin{tabular}{|c|c|c|c|c|c|c|}
\hline & \multirow[t]{2}{*}{ Type of surgery (disease) } & \multirow[t]{2}{*}{$N$} & \multirow[t]{2}{*}{ Time } & \multicolumn{2}{|l|}{ Conversion to } & \multirow[t]{2}{*}{ Complications } \\
\hline & & & & Laparoscopy & Laparotomy & \\
\hline \multirow[t]{8}{*}[14]{} & Total hysterectomy & 105 & 120 & 11 & 2 & 6 \\
\hline & Subtotal hysterectomy & 11 & 180 & & & \\
\hline & Oophorectomy & 43 & 60 & & & \\
\hline & Ovarian cystectomy & 31 & 105 & & & \\
\hline & Salpingectomy & 5 & 60 & & & \\
\hline & Myomectomy & 2 & & & & \\
\hline & Adhesiolysis & 3 & & & & \\
\hline & Total & 200 & a & & & \\
\hline [18] & $\begin{array}{l}\text { Pelvic and/or para-aortic lymph node sampling or } \\
\text { lymphadenectomy (early stage gynecologic malignancies) }\end{array}$ & 21 & 120 & 0 & 0 & 0 \\
\hline [19] & $\begin{array}{l}\text { Risk-reducing salpingo-oophorectomy with and } \\
\text { without hysterectomy }\end{array}$ & 58 & 38.1 & 0 & 0 & 0 \\
\hline$[20]$ & Benign adnexal disease & 9 & N/A & 1 & 0 & 0 \\
\hline$[21]$ & Total hysterectomy & 100 & 80 & 0 & 0 & 0 \\
\hline$[22]^{\mathrm{b}}$ & Laparoscopic-assisted vaginal hysterectomy & 183 & 78.8 & 2 & 0 & 0 \\
\hline \multirow[t]{7}{*}[23]{$^{\mathrm{b}}$} & Salpingo-oophorectomy & 17 & & & & \\
\hline & Cystectomy & 2 & & & & \\
\hline & Ectopic pregnancy (salpingectomy) & 2 & & & & \\
\hline & Myomectomy & 5 & & & & \\
\hline & Laparoscopic assisted vaginal hysterectomy & 1 & & & & \\
\hline & Hysterectomy & 11 & 199 & & & \\
\hline & Total & 38 & a & 0 & 0 & 0 \\
\hline$[24]$ & Adnexal tumors & 94 & 50.33 & 2 & 2 & 0 \\
\hline$[25]$ & $\begin{array}{l}\text { Extraperitoneal para-aortic lymphadenectomy } \\
\text { (locally advanced cervical cancer) }\end{array}$ & 14 & 190 & 0 & 0 & 0 \\
\hline$[26]$ & Low-risk early endometrial cancer & 20 & 105 & 0 & 0 & 0 \\
\hline$[27]$ & Myomectomy & 12 & 100 & 0 & 0 & 0 \\
\hline$[28]$ & $\begin{array}{l}\text { Salpingoophorectomy }(n=9) \text {, ovarian cyst enucleation }(n=5) \text {, } \\
\text { and salpingectomy }(n=2) \text { (benign adnexal pathologies) }\end{array}$ & 16 & 42 & 0 & 0 & 0 \\
\hline$[29]$ & Adnexal lesions & 86 & 64.5 & 2 & 0 & 4 \\
\hline$[30]$ & Adnexal tumors & 12 & 79 & 0 & 0 & 0 \\
\hline$[31]$ & Myomectomy with transumbilical morcellation & 15 & 96.7 & 0 & 0 & 0 \\
\hline$[32]^{\mathrm{b}}$ & Salpingectomy & 30 & 52.6 & 0 & 0 & 0 \\
\hline$[33]^{\mathrm{b}}$ & Hand-assisted laparoscopic surgery (large adnexal tumors) & 43 & 75 & 0 & 0 & 0 \\
\hline$[34]$ & Myomectomy & 15 & 81 & 1 & 0 & 0 \\
\hline$[35]^{\mathrm{b}}$ & Laparoscopically assisted vaginal hysterectomy & 47 & 92.4 & 0 & 0 & 2 \\
\hline$[36]$ & Adnexal tumors & 100 & 55 & 1 & 0 & 0 \\
\hline$[37]$ & Ectopic pregnancy & 12 & 48.5 & 0 & 0 & 2 \\
\hline$[38]$ & Pelvic surgeries & 19 & 96 & 0 & 0 & 0 \\
\hline [39] & Abdominal sacral colpopexy & 10 & 162 & 0 & 0 & 0 \\
\hline \multirow[t]{2}{*}{ [40] } & Salpingectomies & 27 & 70 & 1 & 0 & 0 \\
\hline & Salpingotomies & 5 & & & & \\
\hline$[17]^{\mathrm{b}}$ & Laparoscopic-assisted vaginal hysterectomy & 50 & 122 & 2 & 0 & 1 \\
\hline$[12]$ & Hysterectomy & 11 & 163.3 & 0 & 0 & 2 \\
\hline TOTAL & Different surgical procedures & 1152 & a & $23(1.99 \%)$ & $4(0.35 \%)$ & $17(1.48 \%)$ \\
\hline
\end{tabular}

${ }^{a}$ Operative time varied according to the type of procedure

${ }^{\mathrm{b}}$ Comparative studies between single-port laparoscopic surgery and traditional laparoscopy 
performed by experienced groups in gynecologic surgery $[1,12-17]$.

In this paper, we conducted a MEDLINE literature search of all publications in English language from 2007 to 2011 using the search term "single-port surgery," as well as a review of all references to summarize the existing clinical experience on single-port laparoscopic surgery in gynecology.

\section{Methods}

\section{Sources}

A systematic MEDLINE review of the English language literature from 2007 To 2011 was performed using the search term "single-port surgery," which contained information on single-port laparoscopic surgery in gynecology.

\section{Study selection}

Entrance criteria for the MEDLINE search term "single-port surgery" included: patients undergoing single-port surgery in gynecology. Review articles and case reports were excluded from the analysis. The review of the English language literature identified 995 papers on single-port surgery. A total of 72 papers included gynecologic procedures and 26 studies were selected for further analysis.

\section{Findings}

A total of 72 papers were published from 2007 to 2011 on gynecologic single-port surgery. Twenty-six studies were put together in the Table 1. A total of 1,152 women underwent different surgical procedures by means of single-port surgery. The operative time varied according to the type of procedure. Overall, the conversion rate to conventional laparoscopy was $1.99 \%$, and the conversion rate to laparotomy was $0.35 \%$. The surgical morbidity was low (1.48 \%). Therefore, single-port laparoscopic surgery may be applied to most benign gynecologic surgeries without detrimental effects on clinical outcomes.

The implementation of the single-port surgery in a gynecologic service was evaluated by Lee et al. [41]. They retrospectively evaluated the medical records of 500 consecutive patients undergoing laparotomic or laparoscopic surgery for benign gynecologic diseases. The surgeries included hysterectomy $(n=239)$, adnexal surgery $(n=194)$, myomectomy $(n=33)$, adnexal surgery + myomectomy $(n=18)$, and other procedures $(n=16)$. They divided the patients into five groups of 100 patients each, and they observed an increasing rate of single-port laparoscopic procedures over the period-29\%, $62 \%, 72 \%, 71 \%$, and $86 \%$. In the last group, laparotomy and multiport laparoscopy were required in only $4 \%$ and $10 \%$ of the cases, respectively. They did not notice any differences in the median operative time or complication rate over the study period.

Despite these preliminary optimistic results in the outcomes of single-port surgery, an experienced laparoscopic skill set seems to be essential for the safe and effective completion of surgery [42].

\section{Technique}

The procedure may be typically performed by means of two approaches. The first is single-site surgery, in which two or more conventional ports are placed through a single incision (Fig. 1). The second approach is performed by using a single-port multichannel device, through which multiple instruments and the laparoscope are passed [43].

\section{Instruments and devices}

Different single-port devices have been developed to try to fulfill the requirements of this new surgical technique:

- SILS port multiple instrument access port (Covidien ${ }^{\circledR}$, Mansfield, MA) (Fig. 2);

- TriPort (Advanced Surgical Concepts, Wicklow, Ireland);

- GelPOINT system (Applied Medical, Rancho Santa Margarita, CA) (Fig. 3);

- AirSeal DPS (SurgiQuest, Orange, CT);

- R-Port (Advanced Surgical Concepts, Wicklow, Ireland);

- Quadriport (Advanced Surgical Concepts, Wicklow, Ireland);

- Uni-X single-port access laparoscopic system (PNavel systems, Cleveland, $\mathrm{OH}$ );

- Single-site laparoscopy access system (Ethicon Endosurgery, Cincinnati, OH) (Fig. 4);

- SITRACC (Edlo Company, Porto Alegre, Brazil) (Fig. 5).

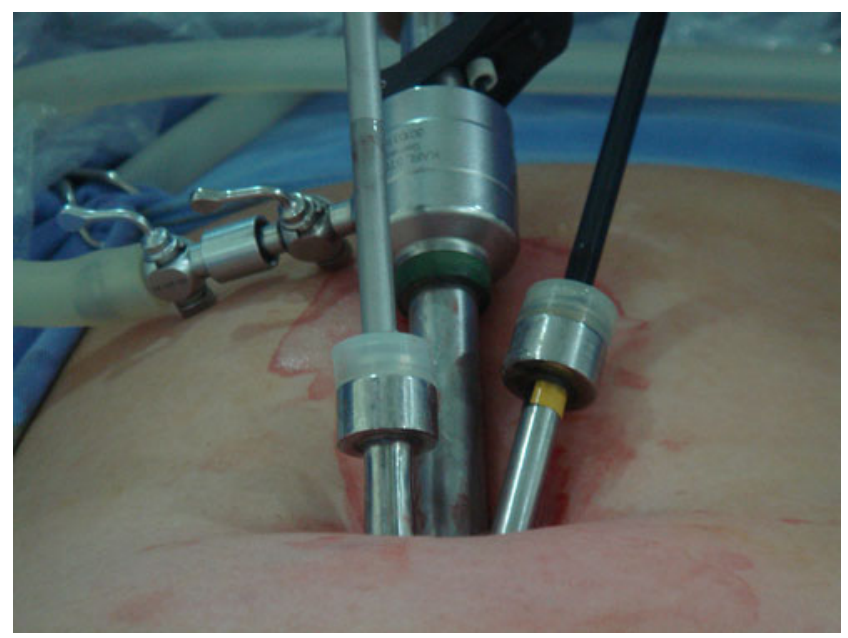

Fig. 1 Right salpingectomy performed by means of three conventional trocars placed inside the umbilicus 

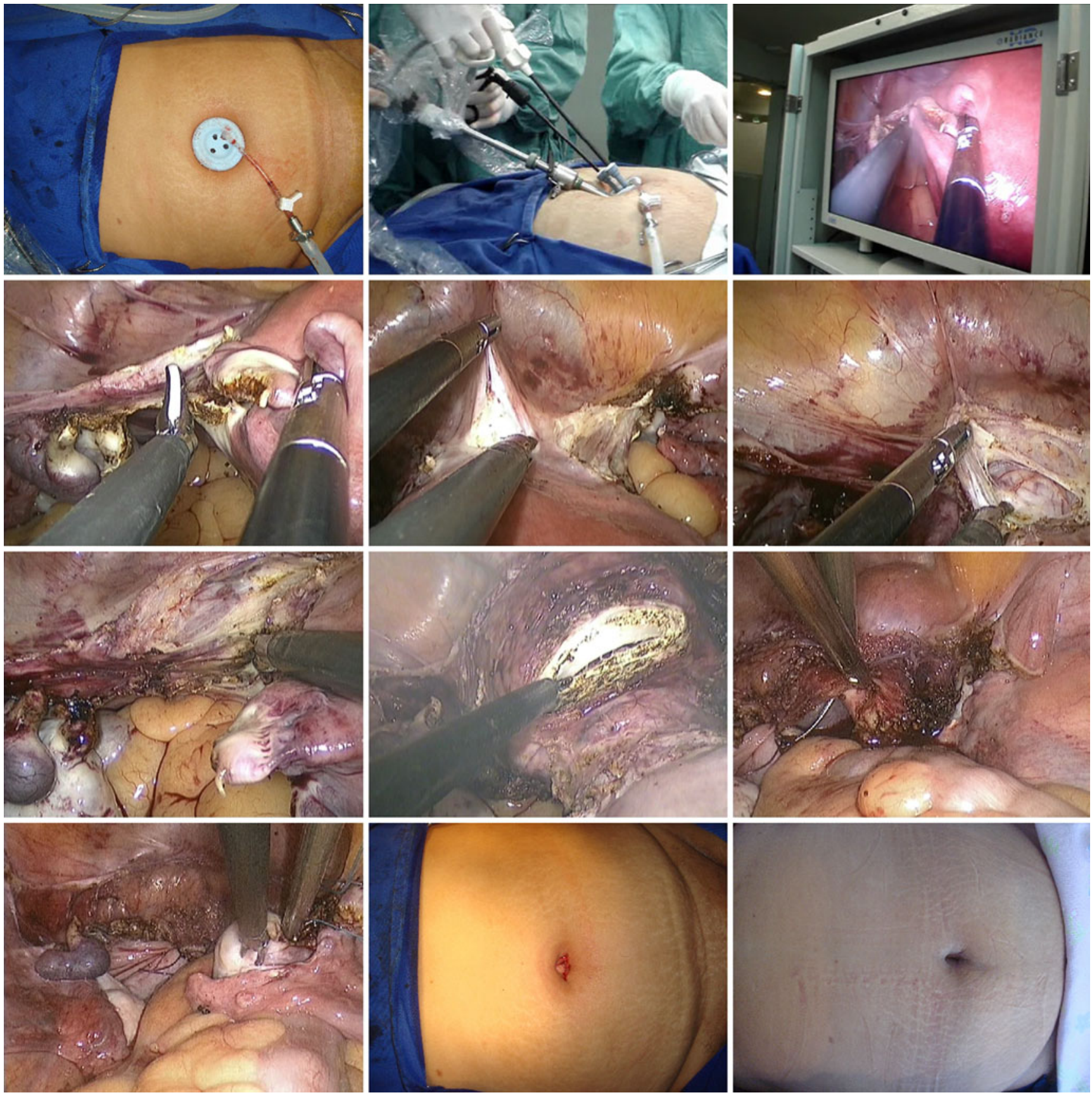

Fig. 2 Single-port total laparoscopic hysterectomy using the SILS device

One study [44] compared the technical performance between conventional laparoscopic and single-port devices (SILS port, the TriPort access system, and the GelPOINT system) in a surgical simulator. Overall, the TriPort was more challenging for novices to use in learning the singleport procedure than either the SILS port or the GelPOINT system. The GelPOINT system offered the most consistent platform for single-port surgery performance and novice skill acquisition. In our preliminary experience using the single-site surgery, the SILS port, the SITRACC device, the GelPoint, and the single-site laparoscopy access system, both the SILS platform and the single-site laparoscopy access system seemed to be the more comfortable devices for pelvic gynecologic procedures.

Also, the development of articulating and bent instrumentation permits triangulation intracorporeally despite the close proximity of several instruments via a single port [42]. 


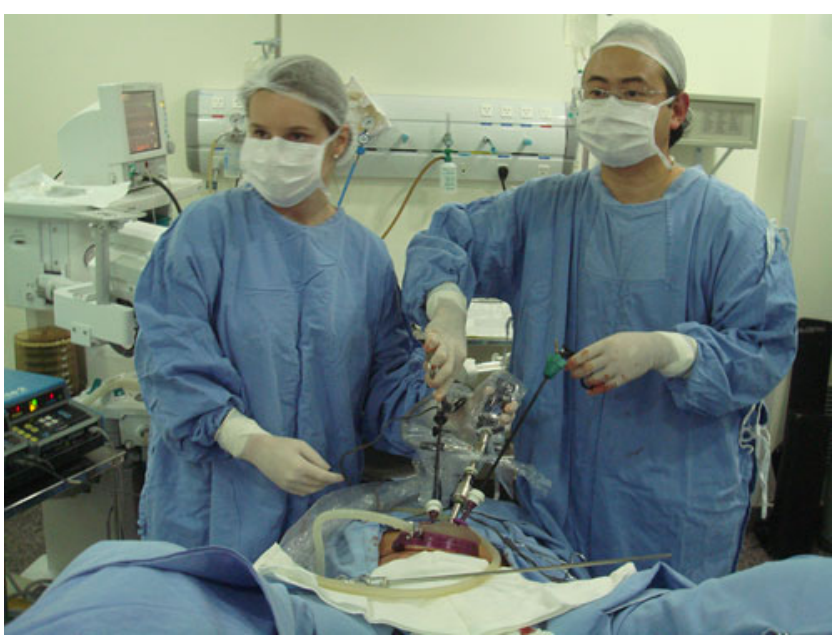

Fig. 3 Single-port laparoscopic salpingectomy using the GelPOINT system

\section{Learning curve}

Whenever a new surgical technique is introduced into clinical practice, there is a specific learning curve that surgeons have to manage in order to improve their skills and the safety of the procedure.

Paek et al. [21] evaluated 100 patients who underwent single-port total laparoscopic hysterectomy to define the learning curve for the procedure. The median time until the removal of the specimen was $45 \mathrm{~min}$, and the median time for closure of the vaginal cuff was $18 \mathrm{~min}$. The median total operative time (from skin opening to closure) was $80 \mathrm{~min}$. Proficiency at the procedure was achieved after 40 cases. The time for vaginal closure the decreased significantly from the first 20 cases to the next, and the total operating time decreased significantly from the second 20 cases to the next.
In the experience of Song et al. [45], the proficiency and plateau were determined after approximately 25 and 75 cases of single-port laparoscopic-assisted vaginal hysterectomies, respectively. Conversely, Lee et al. [46] showed a shorter learning curve for such procedure. They observed a tendency toward a decreased operative time after ten cases of single-port laparoscopic-assisted vaginal hysterectomy.

\section{Comparative studies}

Prospective randomized studies comparing the outcomes of single-port and traditional laparoscopic surgeries are required to establish the actual benefits and disadvantages of the new minimally invasive technique.

Lee et al. [47] compared the perioperative outcomes between 17 single-port laparoscopic adnexal surgeries and 34 conventional laparoscopic adnexal surgeries. There were no differences between the two groups in median operative time (64 vs. $57.5 \mathrm{~min}, p=0.252$ ), the number of patients that requested additional parenteral non-steroidal anti-inflammatory drugs ( 7 patients vs. 19 patients, $p=0.597$ ), and the absolute decrease $(1.3 \mathrm{mg} / \mathrm{dl}$ vs. $1.1 \mathrm{mg} / \mathrm{dl}, p=0.640)$ from preoperative hemoglobin to postoperative day 1 measurements. No blood transfusion was required. There were no complications.

From January to June 2009, Yoon et al. [32] conducted a comparative study between single-port laparoscopic salpingectomy $(n=30)$ and conventional laparoscopic salpingectomy $(n=30)$ for the treatment of tubal pregnancy. All operations were completed successfully. No significant difference was observed between the two groups in terms of mean operative time $(52.6 \pm 16.1 \mathrm{~min}$ vs $46.8 \pm 16.2 \mathrm{~min} ; p=$ $0.174)$, mean difference between pre- and postoperative hemoglobin $(1.7 \pm 0.8 \mathrm{~g} / \mathrm{dl}$ vs $1.8 \pm 1.0 \mathrm{~g} / \mathrm{dl} ; p=0.636)$, or mean postoperative hospital stay $(2.4 \pm 0.5$ days vs $2.4 \pm$
Fig. 4 Single-port total laparoscopic hysterectomy using the single-site laparoscopy access system
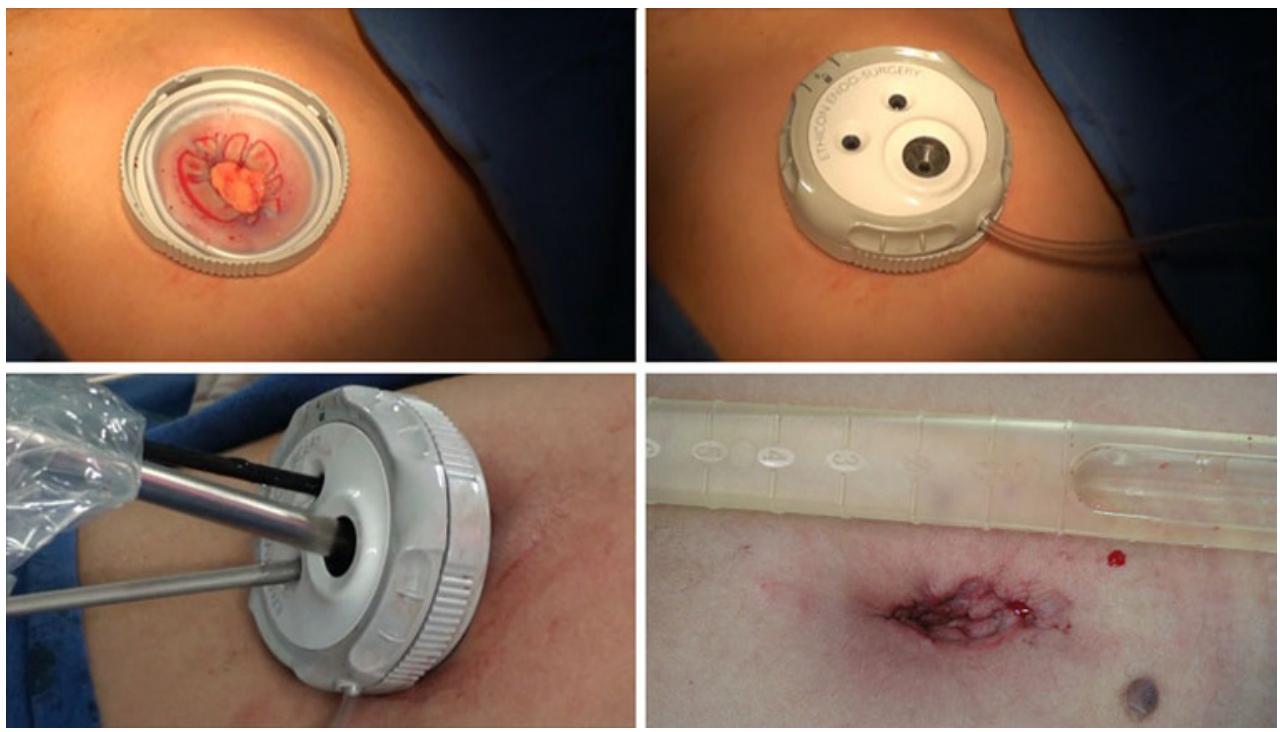
Fig. 5 Single-port total laparoscopic hysterectomy using the SITRACC
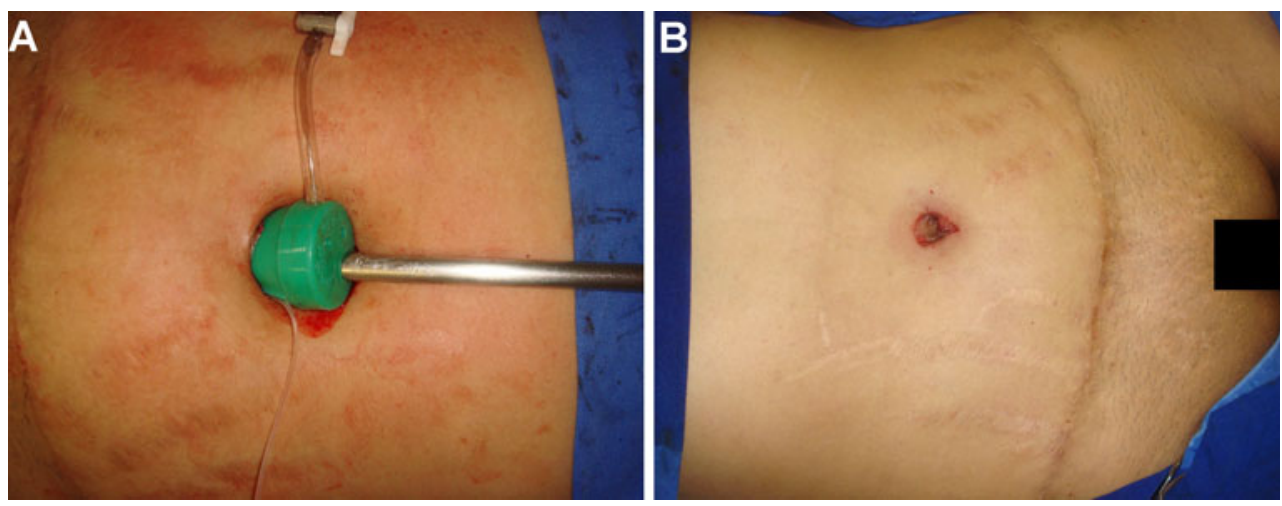

0.9 days; $p=1.000$ ). No complications were encountered in either group, and there was no conversion to conventional laparoscopy in the single-port surgery group.

In a retrospective study, Yim et al. [13] compared surgical outcomes and postoperative pain between single-port total laparoscopic hysterectomy $(n=52)$ and conventional fourport total laparoscopic hysterectomy $(n=105)$. The singleport group had less intraoperative blood loss $(p<0.001)$, shorter hospital stay $(p=0.001)$, and earlier diet intake ( $p<$ 0.001 ) compared with the conventional group. There was no difference in perioperative complications. Immediate postoperative pain score was lower in the single-port group ( $p<$ 0.001). Postoperative pain after 6 and $24 \mathrm{~h}$ was lower in single-port group with marginal statistical significance.

Kim et al. [48] retrospectively compared the perioperative outcomes of single-port laparoscopic-assisted vaginal hysterectomy $(n=43)$ and conventional laparoscopic-assisted vaginal hysterectomy $(n=43)$. There was one conversion to laparotomy in the former group and two in the latter group. Additionally, three patients in the former group needed the placement of additional trocars (conversion to traditional laparoscopy). The operative time (119 vs. $124 \mathrm{~min} ; p=0.6$ ), estimated blood loss ( 369 vs. $378 \mathrm{ml} ; p=0.9$ ), drop in hemoglobin preoperatively to postoperative day 1 (14.6\% vs. $12.1 \% ; p=0.2$ ), and postoperative hospital stay were comparable between both groups ( 2.8 vs. 2.7 days; $p=0.9$ ). Singleport laparoscopic-assisted vaginal hysterectomy was associated with reduced postoperative pain. There were no complications, including reoperation, adjacent organ damage, and any postoperative morbidity, in both groups.

Escobar et al. [49] compared the surgical outcomes of single-port laparoscopy for the surgical treatment of presumed early stage endometrial cancer (stage I or occult stage II endometrial cancer) to laparoscopy and robotics. Thirty patients were included in each group. There were no significant differences in median operating time or estimated blood loss between the three groups. The median number of pelvic lymph nodes obtained was significantly higher in the robotic $(n=17)$ and single-port group $(n=16)$ compared with the laparoscopy group $(n=13)$. However, there was no significant difference in the median number of para-aortic nodes obtained between the three groups. There was no significant difference between the groups in length of hospital stay, comorbid conditions, complication rates, or operative times.

\section{Training courses}

Training courses allow inexperienced surgeons to learn and improve minimally invasive surgical techniques. They play an important role in the acquisition of specific skills in the single-port approach.

Botden et al. [50] evaluated 15 participants performing three basic tasks (translocation, clip and cut, and tissue dissection, based on the fundamentals of laparoscopic surgery) in the box trainer in laparoscopy and single-port access settings with both (conventional) crossed and curved instruments. Although conventional laparoscopy appeared most effective for proper dissection and tissue exposure, single-port access surgery showed potential. Especially in the tissue dissection task, there was no significant difference in time or errors between conventional laparoscopy and single-port surgery, using especially designed curved instruments.

In the study of Montero et al. [51], single-port laparoscopic surgery was associated with poorer performance and increased surgeon workload compared with standard laparoscopy. It was improved when angulated instruments were used for simulated tasks instead of straight instruments, but it still remained inferior to standard laparoscopy. Therefore, specialized training courses seem to be effective for developing single-port laparoscopic skills [52].

\section{Robotics single-port surgery}

Robotics may enhance surgical skills during single-port laparoscopic surgery and decrease the learning curve.

In 2011, Escobar et al. [53] evaluated a novel single-port robotic platform in the cadaver model. They demonstrated that the performance of various procedures in gynecologic oncology using the new da Vinci ${ }^{\circledR}$ single-site robotic platform is feasible and, more importantly, reproducible in the cadaver model. 
In the initial series of Nam et al. [54], they operated on seven patients using robotics to perform single-port transumbilical total hysterectomy. Procedures included total hysterectomy due to benign gynecological disease $(n=5)$, extra-fascial hysterectomy due to carcinoma in situ of the cervix $(n=1)$, and radical hysterectomy due to cervical cancer IB1 $(n=1)$. The median total operative time was $109 \mathrm{~min}$ (range, 105 to $311 \mathrm{~min}$ ); the median blood loss was $100 \mathrm{ml}$ (range, 10 to $750 \mathrm{ml}$ ), and the median weight of the resected uteri was $200 \mathrm{~g}$ (range, 40 to $310 \mathrm{~g}$ ). One benign case was converted to threeport robotic surgery due to severe pelvic adhesions, and no post-operative complications occurred.

\section{Controversies}

Most studies do not show any superiority of the single-port access over conventional laparoscopic procedures [14]. The possible cosmetic advantage was not proved yet. Depending on the shape of the patient's umbilical scar, the skin incision cannot be performed completely inside the umbilicus. Some studies demonstrated a reduction in the postoperative pain using the single-port access [13, 17, 48]; however, one could think that maybe a bigger single incision could be more painful that four smaller incisions and could have an increased risk of incisional hernia.

Chen et al. [17] compared the immediate results of patients undergoing either two-channel single-port laparoscopicassisted vaginal hysterectomy $(n=50)$ or conventional multiport laparoscopic-assisted vaginal hysterectomy $(n=50)$. There were no statistically significant differences in operative time, estimated blood loss, time to first flatus, intraoperative and immediate postoperative complications, shoulder tip pain, or length of hospital stay between the two groups. However, postoperative pain was significantly less in the single-port group compared with the conventional group, as evidenced by lower mean scores on the visual analog scale and less mean accumulated dose of postoperative analgesics. Conversely, a randomized prospective study of single-port and four-port approaches for hysterectomy conducted by Jung et al. [2] did not demonstrate any reduction of the postoperative pain with single-port access. The surgical outcomes were similar for both groups.

Tsimogiannis et al. [55] conducted a randomized study of 20 patients undergoing standard four-port laparoscopic cholecystectomy and 20 patients undergoing LESS. They observed a higher inflammatory reaction in the latter group, demonstrated by the higher levels of postoperative $\alpha$ defensins in this group. However, pain was statistically significantly less for the LESS group at the 24-h interval, and less pain medication was needed for LESS patients after the sixth postoperative hour.

In the experience of Gunderson et al. [56], the risk of umbilical hernia with laparoendoscopic single-site surgery was $2.4 \%$. When they excluded some patients ("high risk" subjects for incisional disruption) from the analysis, the umbilical hernia rate was $0.5 \%$.

\section{Final considerations}

Single-port surgery is the latest innovation in minimally invasive surgery and seems to be feasible, reproducible, and safe to perform different gynecologic procedures. Reduced pain and improved cosmesis are supposed to be the potential advantages of these procedures, but it was not completely confirmed yet! Further studies are still necessary to establish the real benefits of this new surgical approach over the traditional multi-port laparoscopy.

Declaration of interest The authors report no conflicts of interest. The authors alone are responsible for the content and writing of the paper.

\section{References}

1. Mohd J, Siow A (2011) Single-port access total laparoscopic hysterectomy for stage 1A1 cancer of the cervix. Singapore Med J 52(6):e111-e114

2. Jung YW, Lee M, Yim GW, Lee SH, Paek JH, Kwon HY, Nam EJ, Kim SW, Kim YT (2011) A randomized prospective study of single-port and four-port approaches for hysterectomy in terms of postoperative pain. Surg Endosc 25(8):2462-2469

3. Branco AW, Kondo W, Stunitz LC, Filho AJ, de George MA (2009) Transumbilical laparoscopic urological surgery: are special devices strictly necessary? BJU Int 104(8):1136-1142

4. de George MA, Rangel M, Noda RW, Kondo W (2009) Laparoscopic transumbilical cholecystectomy: surgical technique. JSLS 13(4):536-541

5. Romanelli JR, Earle DB (2009) Single-port laparoscopic surgery: an overview. Surg Endosc 23(7):1419-1427

6. Canes D, Desai MM, Aron M, Haber GP, Goel RK, Stein RJ, Kaouk JH, Gill IS (2008) Transumbilical single-port surgery: evolution and current status. Eur Urol 54(5):1020-1029

7. Fader AN, Escobar PF (2009) Laparoendoscopic single-site surgery (LESS) in gynecologic oncology: technique and initial report. Gynecol Oncol 114(2):157-161

8. Zhu JF (2009) Which term is better: SILS, SPA, LESS, E-NOTES, or TUES? Surg Endosc 23(5):1164-1165

9. Wheeless CR Jr (1969) A rapid, inexpensive, and effective method of surgical sterilization by laparoscopy. J Reprod Med 3:65-69

10. Wheeless CR Jr, Thompson BH (1973) Laparoscopic sterilization. Review of 3600 cases. Obstet Gynecol 42(5):751-758

11. Pelosi MA, Pelosi MA 3rd (1991) Laparoscopic hysterectomy with bilateral salpingo-oophorectomy using a single umbilical puncture. N J Med 88(10):721-726

12. Phongnarisorn C, Chinthakanan O (2011) Transumbilical singleincision laparoscopic hysterectomy with conventional laparoscopic instruments in patients with symptomatic leiomyoma and/or adenomyosis. Arch Gynecol Obstet 284(4):893-900

13. Yim GW, Jung YW, Paek J, Lee SH, Kwon HY, Nam EJ, Kim S, Kim JH, Kim YT, Kim SW (2010) Transumbilical single-port 
access versus conventional total laparoscopic hysterectomy: surgical outcomes. Am J Obstet Gynecol 203(1):26.e1-26.e6

14. Park HS, Kim TJ, Song T, Kim MK, Lee YY, Choi CH, Lee JW, Kim BG, Bae DS (2011) Single-port access (SPA) laparoscopic surgery in gynecology: a surgeon's experience with an initial 200 cases. Eur J Obstet Gynecol Reprod Biol 154(1):81-84

15. Paek J, Nam EJ, Kim YT, Kim SW (2011) Overcoming technical difficulties with single-port access laparoscopic surgery in gynecology: using conventional laparoscopic instruments. J Laparoendosc Adv Surg Tech A 21(2):137-141

16. Lee JH, Choi JS, Jeon SW, Son CE, Hong JH, Bae JW (2011) A prospective comparison of single-port laparoscopically assisted vaginal hysterectomy using transumbilical GelPort access and multiport laparoscopically assisted vaginal hysterectomy. Eur J Obstet Gynecol Reprod Biol 158(2):294-297

17. Chen YJ, Wang PH, Ocampo EJ, Twu NF, Yen MS, Chao KC (2011) Single-port compared with conventional laparoscopicassisted vaginal hysterectomy: a randomized controlled trial. Obstet Gynecol 117(4):906-912

18. Escobar PF, Fader AN, Rasool N, Espalliat LR (2010) Single-port laparoscopic pelvic and para-aortic lymph node sampling or lymphadenectomy: development of a technique and instrumentation. Int J Gynecol Cancer 20(7):1268-1273

19. Escobar PF, Starks DC, Fader AN, Barber M, Rojas-Espalliat L (2010) Single-port risk-reducing salpingo-oophorectomy with and without hysterectomy: surgical outcomes and learning curve analysis. Gynecol Oncol 119(1):43-47

20. Escobar PF, Bedaiwy MA, Fader AN, Falcone T (2010) Laparoendoscopic single-site (LESS) surgery in patients with benign adnexal disease. Fertil Steril 93(6):2074.e7-2074.e10

21. Paek J, Kim SW, Lee SH, Lee M, Yim GW, Nam EJ, Kim YT (2011) Learning curve and surgical outcome for single-port access total laparoscopic hysterectomy in 100 consecutive cases. Gynecol Obstet Invest 72(4):227-233

22. Jung MH, Lee BY (2011) Transumbilical single-port laparoscopicassisted vaginal hysterectomy via $12-\mathrm{mm}$ trocar incision site. J Laparoendosc Adv Surg Tech A 21(7):599-602

23. Ichikawa M, Akira S, Mine K, Ohuchi N, Iwasaki N, Kurose K, Takeshita T (2011) Evaluation of laparoendoscopic single-site gynecologic surgery with a multitrocar access system. J Nihon Med Sch 78(4):235-240

24. Kim WC, Lee JE, Kwon YS, Koo YJ, Lee IH, Lim KT (2011) Laparoendoscopic single-site surgery (LESS) for adnexal tumors: one surgeon's initial experience over a one-year period. Eur J Obstet Gynecol Reprod Biol 158(2):265-268

25. Gouy S, Kane A, Uzan C, Gauthier T, Gilmore J, Morice P (2011) Single-port laparoscopy and extraperitoneal para-aortic lymphadenectomy: about fourteen consecutive cases. Gynecol Oncol 123 (2):329-332

26. Fanfani F, Rossitto C, Gagliardi ML, Gallotta V, Gueli Alletti S, Scambia G, Fagotti A (2012) Total laparoendoscopic single-site surgery (LESS) hysterectomy in low-risk early endometrial cancer: a pilot study. Surg Endosc 26(1):41-46

27. Yoshiki N, Okawa T, Kubota T (2011) Single-incision laparoscopic myomectomy with intracorporeal suturing. Fertil Steril 95 (7):2426-2428

28. Mereu L, Angioni S, Melis GB, Mencaglia L (2010) Single access laparoscopy for adnexal pathologies using a novel reusable port and curved instruments. Int J Gynaecol Obstet 109(1):78-80

29. Jung YW, Choi YM, Chung CK, Yim GW, Lee M, Lee SH, Paek JH, Nam EJ, Kim YT, Kim SW (2011) Single port transumbilical laparoscopic surgery for adnexal lesions: a single center experience in Korea. Eur J Obstet Gynecol Reprod Biol 155(2):221-224

30. Lim MC, Kim TJ, Kang S, Bae DS, Park SY, Seo SS (2009) Embryonic natural orifice transumbilical endoscopic surgery (E-NOTES) for adnexal tumors. Surg Endosc 23(11):2445-2449
31. Kim YW, Park BJ, Ro DY, Kim TE (2010) Single-port laparoscopic myomectomy using a new single-port transumbilical morcellation system: initial clinical study. J Minim Invasive Gynecol 17(5):587-592

32. Yoon BS, Park H, Seong SJ, Park CT, Jun HS, Kim IH (2011) Single-port versus conventional laparoscopic salpingectomy in tubal pregnancy: a comparison of surgical outcomes. Eur J Obstet Gynecol Reprod Biol 159(1):190-193

33. Roh HJ, Lee SJ, Ahn JW, Kwon YS, Cho HJ, Kim DY (2012) Single-port-access, hand-assisted laparoscopic surgery for benign large adnexal tumors versus single-port pure laparoscopic surgery for adnexal tumors. Surg Endosc 26(3):693-703

34. Lee JH, Choi JS, Jeon SW, Son CE, Lee SJ, Lee YS (2010) Singleport laparoscopic myomectomy using transumbilical GelPort access. Eur J Obstet Gynecol Reprod Biol 153(1):81-84

35. Lee JH, Choi JS, Hong JH, Joo KJ, Kim BY (2011) Does conventional or single port laparoscopically assisted vaginal hysterectomy affect female sexual function? Acta Obstet Gynecol Scand 90 (12):1410-1415

36. Takeda A, Imoto S, Mori M, Nakano T, Nakamura H (2011) Isobaric laparoendoscopic single-site surgery with wound retractor for adnexal tumors: a single center experience with the initial 100 cases. Eur J Obstet Gynecol Reprod Biol 157(2):190-196

37. Takeda A, Imoto S, Mori M, Nakano T, Nakamura H (2011) Early experience with isobaric laparoendoscopic single-site surgery using a wound retractor for the management of ectopic pregnancy. Eur J Obstet Gynecol Reprod Biol 154(2):209-214

38. Rettenmaier MA, Abaid LN, Erwin MR, John CR, Micha JP, Brown JV 3rd, Goldstein BH (2009) A retrospective review of the GelPort system in single-port access pelvic surgery. J Minim Invasive Gynecol 16(6):743-747

39. White WM, Goel RK, Swartz MA, Moore C, Rackley RR, Kaouk JH (2009) Single-port laparoscopic abdominal sacral colpopexy: initial experience and comparative outcomes. Urology 74(5):1008-1012

40. Lamourdedieu C, Rua S, Lazard A, Marcelli M, Cravello L, Gamerre M, Agostini A (2011) Surgical treatment of ectopic pregnancy by single port access with SILS ${ }^{\circledR}$ system: preliminary study. J Gynecol Obstet Biol Reprod (Paris) 40(7):620-625

41. Lee M, Kim SW, Nam EJ, Yim GW, Kim S, Kim YT (2011) Single-port laparoscopic surgery is applicable to most gynecologic surgery: a single surgeon's experience. Surg Endosc (in press)

42. Kommu SS, Rané A (2009) Devices for laparoendoscopic singlesite surgery in urology. Expert Rev Med Devices 6(1):95-103

43. Fader AN, Levinson KL, Gunderson CC, Winder AD, Escobar PF (2011) Laparoendoscopic single-site surgery in gynaecology: a new frontier in minimally invasive surgery. J Minim Access Surg 7(1):71-77

44. Brown-Clerk B, de Laveaga AE, LaGrange CA, Wirth LM, Lowndes BR, Hallbeck MS (2011) Laparoendoscopic single-site (LESS) surgery versus conventional laparoscopic surgery: comparison of surgical port performance in a surgical simulator with novices. Surg Endosc 25(7):2210-2218

45. Song T, Kim TJ, Lee YY, Choi CH, Lee JW, Kim BG, Bae DS (2011) What is the learning curve for single-port access laparoscopicassisted vaginal hysterectomy? Eur J Obstet Gynecol Reprod Biol 158(1):93-96

46. Lee YY, Kim TJ, Kim CJ, Kang H, Choi CH, Lee JW, Kim BG, Lee JH, Bae DS (2009) Single-port access laparoscopic-assisted vaginal hysterectomy: a novel method with a wound retractor and a glove. J Minim Invasive Gynecol 16(4):450-453

47. Lee YY, Kim TJ, Kim CJ, Park HS, Choi CH, Lee JW, Lee JH, Bae DS, Kim BG (2010) Single port access laparoscopic adnexal surgery versus conventional laparoscopic adnexal surgery: a comparison of peri-operative outcomes. Eur J Obstet Gynecol Reprod Biol 151(2):181-184

48. Kim TJ, Lee YY, Cha HH, Kim CJ, Choi CH, Lee JW, Bae DS, Lee JH, Kim BG (2010) Single-port-access laparoscopic-assisted 
vaginal hysterectomy versus conventional laparoscopic-assisted vaginal hysterectomy: a comparison of perioperative outcomes. Surg Endosc 24(9):2248-2252

49. Escobar PF, Frumovitz M, Soliman PT, Frasure HE, Fader AN, Schmeler KM, Ramirez PT (2011) Comparison of single-port laparoscopy, standard laparoscopy, and robotic surgery in patients with endometrial cancer. Ann Surg Oncol (in press)

50. Botden S, Strijkers R, Fransen S, Stassen L, Bouvy N (2011) The use of curved vs. straight instruments in single port access surgery, on standardized box trainer tasks. Surg Endosc 25(8):2703-2710

51. Montero PN, Acker CE, Heniford BT, Stefanidis D (2011) Single incision laparoscopic surgery (SILS) is associated with poorer performance and increased surgeon workload compared with standard laparoscopy. Am Surg 77(1):73-77

52. Yang B, Xu B, Zeng Q, Altunrende F, Wang H, Xiao L, Wang L, $\mathrm{Xu}$ C, Sun Y (2011) A specialized course of basic skills training for single-port laparoscopic surgery. Surgery 149(6):766-775
53. Escobar PF, Kebria M, Falcone T (2011) Evaluation of a novel single-port robotic platform in the cadaver model for the performance of various procedures in gynecologic oncology. Gynecol Oncol 120(3):380-384

54. Nam EJ, Kim SW, Lee M, Yim GW, Paek JH, Lee SH, Kim S, Kim JH, Kim JW, Kim YT (2011) Robotic single-port transumbilical total hysterectomy: a pilot study. J Gynecol Oncol 22(2):120-126

55. Tsimogiannis KE, Tellis CC, Tselepis AD, Pappas-Gogos G, Bakola MS, Tsimoyiannis EC, Simopoulos CE, Pitiakoudis M (2012) $\alpha$-Defensins and hsCRP levels in inflammatory response of standard and laparoendoscopic single-site cholecystectomy. Surg Endosc 26(3):627-631

56. Gunderson CC, Knight J, Ybanez-Morano J, Ritter C, Escobar PF, Ibeanu O, Grumbine FC, Bedaiwy MA, Hurd WW, Fader AN (2012) The risk of umbilical hernia and other complications with laparoendoscopic single-site surgery. J Minim Invasive Gynecol 19(1):40-45 